\title{
PENGARUH PENGHAYATAN PEERS SUPPORT TERHADAP SCHOOL ENGAGEMENT SISWA KELAS X SMA "X" BANDUNG
}

\author{
Dhanawa Rylla Insani ${ }^{1}$, Jane Savitri ${ }^{2}$ \\ Fakultas Psikologi Universitas Kristen Maranatha \\ dhana.rylla@gmail.com
}

\begin{abstract}
This study was conducted to determine the effect of appreciation of peers support for school engagement in Class X Students of SMA " $X$ " Bandung which numbered 292 students. The method in this study uses influence research. The measuring instrument used was compiled by Savitri (2018) which came from the theory of school engagement by Fredricks (2004). Peers support measuring instruments are arranged by researchers based on peer support theory by House (1981). Based on statistical data processing on 292 students of class X SMA "X" Bandung, it was found that there was a significant effect of peer support on types of school engagement, namely behavioral engagement $\left(R^{2}=0.177\right)$, emotional engagement $\left(R^{2}=\right.$ $0.236)$, and cognitive engagement $\left(R^{2}=0.132\right)$.
\end{abstract}

Keywords: appraisal support, emotional support, informative support, instrumental support, peer support, school engagement

\begin{abstract}
ABSTRAK
Penelitian ini dilakukan untuk mengetahui pengaruh penghayatan peers support terhadap school engagement pada Siswa Kelas X SMA "X" Bandung sejumlah 292 siswa. Metode dalam penelitian ini menggunakan penelitian pengaruh. Alat ukur yang digunakan disusun oleh Savitri (2018) yang berasal dari teori school engagement oleh Fredricks (2004), Alat ukur peers support disusun oleh peneliti berdasarkan teori peers support oleh House (1981). Berdasarkan pengolahan data ditemukan bahwa terdapat pengaruh yang signifikan dari peers support terhadap tipe-tipe school engagement, yaitu behavioral engagement $\left(\mathrm{R}^{2}=0,177\right)$, emotional engagement $\left(\mathrm{R}^{2}=0,236\right)$, dan cognitive engagement $\left(\mathrm{R}^{2}=0,132\right)$.
\end{abstract}

Kata kunci: Dukungan emosional, dukungan instrumental, dukungan informatif, dukungan penghargaan, peers support, school engagement 


\section{PENDAHULUAN}

SMA "X" Bandung adalah sekolah menengah atas swasta yang menganut dan menerapkan sistem asrama (boarding school) dan menekankan kedisiplinan. Kedisiplinan di dalam kehidupan berasrama SMA "X" Bandung ini diterapkan sejak awal para siswa memasuki sekolah ini hingga akhir masa sekolah yaitu ketika siswa sudah lulus jenjang SMA. Kehidupan berasrama siswa yang disiplin selama berada di SMA " $X$ " Bandung ini diterapkan sebagai landasan cara hidup selama di asrama. Kehidupan berasrama membuat para siswa akan terus berinteraksi dan menjalin relasi antara satu sama lain terutama teman sebayanya di dalam satu angkatan selama bersekolah di lingkungan SMA "X" Bandung. Hal tersebut kemudian melahirkan salah satu budaya khas yang terbentuk sejak awal berdirinya SMA "X" Bandung yang dinamakan budaya KORSA. KORSA adalah singkatan dari Komando Satu Rasa, yang berarti para siswa harus melewati hari-harinya selama berada di SMA " $X$ " baik di asrama maupun di sekolah dengan saling peduli dengan satu sama lain. KORSA dibentuk dan ditanamkan pada siswa sejak awal tiga bulan masa karantina atau masa basis. KORSA mengajarkan jika salah satu siswa berbuat suatu kesalahan maka kesalahan tersebut merupakan kesalahan dan tanggungjawab bersama. Pada masa SMA tentunya remaja menjalani kegiatan sekolah secara beragam. Terdapat remaja yang terlibat dengan kegiatan yang diselenggarakan sekolah ada pula remaja yang kurang terlibat dengan kegiatan sekolah. Siswa yang belajar pada Sekolah Menengah Atas (SMA) dikategorikan sebagai remaja awal. Menurut Santrock (2003), remaja awal adalah suatu perkembangan transisi antara masa anak-anak dan masa dewasa yang mencakup perubahan biologis, kognitif, dan sosial-emosional. Pada tahap remaja awal, individu menghabiskan lebih banyak waktu dengan teman sebaya dan lebih sedikit waktu yang dihabiskan bersama orangtua dan keluarga. Teman sebaya memiliki dampak terhadap perkembangan seorang remaja. Di dalam pergaulan masa remaja, teman sebaya 
Vol. 2 No.2, Agustus-2020

memiliki peran penting terutama pada tahap perkembangan, individu yang memiliki teman dapat meningkatkan minat mereka terhadap pendidikan. Menurut Fredricks (2004), salah satu factor yang dapat memengaruhi keterlibatan siswa di sekolah (school engagement) adalah teman sebaya.

School engagement dikonseptualisasikan sebagai konstruk multidimensional yang meliputi komponen behavioral, emotional, dan cognitive engagement (Fredericks, Blumenfeld \& Paris, 2004). Konstruk multidimensional pada teori ini berarti bahwa tipe-tipe school engagement yaitu behavioral, emotional, dan cognitive engagement tidak dilihat sebagai satu kesatuan atau total untuk mengukur school engagement siswa SMA "X" Bandung. Berdasarkan survei awal yang dilakukan dari 10 siswa, 7 orang diantaranya $(70 \%)$, menyatakan bahwa mereka aktif dalam kegiatan ekstrakulikuler yang diselenggarakan setiap hari sabtu di sekolah dan selalu mengerjakan tugas yang diberikan oleh guru. Kemudian, sebanyak 5 orang siswa (50\%) merasa senang dengan cara guru mengajar di dalam kelas yang beberapa kali menerapkan metode belajar yang beragam seperti dengan menonton film. Lalu, sebanyak 6 orang siswa (60\%) menyatakan bahwa mereka mempelajari materi yang diberikan guru dengan membuat catatan pribadi dengan bahasa sendiri yang lebih mudah dimengerti untuk memahami materi lebih dalam.

Meskipun para siswa menunjukkan keterlibatan yang beragam, namun berdasarkan wawancara dari guru BK SMA “X” Bandung, Guru kelas mengeluhkan sikap para siswa ketika melaksanakan kegiatan belajar di dalam kelas. Siswa seringkali menunda-nunda dalam mengerjakan tugas yang diberikan di kelas. Siswa akan mengobrol terlebih dahulu dengan temannya sebelum akhirnya mengerjakan tugas setelah ditegur terlebih dahulu oleh guru. Guru juga mengatakan bahwa beberapa siswa sering kedapatan sedang tidur di kelas saat pelajaran sedang berlangsung. Dari survei awal yang di lakukan tersebut, terlihat keterlibatan siswa 
kelas X SMA “X” Bandung yang merupakan sekolah asrama cukup beragam di dalam kegiatan belajar di sekolah.

School engagement ini dipengaruhi oleh beberapa faktor salah satunya adalah peers support. Peer support atau dukungan sosial dari teman sebaya berhubungan dengan tingginya school engagement di sekolah (Perdue, Mansezke \& Estell, dalam Estell \& Perdue, 2013). Pernyataan tersebut didukung oleh hasil penelitian Wang dan Eccles (2012) yang mengasosiasikan dukungan sosial dari teman sebaya dengan meningkatnya keterlibatan siswa di kegiatan ekstrakurikuler, identifikasi sekolah, dan penilaian pembelajaran di sekolah. Halhal tersebut diatas merupakan karakteristik bentuk dukungan sosial yang didapatkan dari peers yang dikemukakan oleh House (dalam Vaux,1988).

Hal-hal tersebut membuat hubungan peers antar siswa kelas X di SMA "X" Bandung memiliki perbedaan dengan SMA lain karena sistem asrama yang selalu mempertemukan siswa satu sama lain selama bersekolah di SMA "X” Bandung. Berdasarkan survei awal yang dilakukan yang dilakukan dengan wawancara dengan 10 orang siswa, 4 orang siswa (40\%) menghayati bahwa mereka sering dihibur oleh teman sekelas atau teman sekamar di asrama ketika mereka mengalami masalah. 3 orang siswa (30\%) menyatakan bahwa mereka pernah dipinjami uang oleh temannya ketika di akhir bulan belum menerima kiriman dari orang tua. Ada pula 4 siswa (40\%) yang menyatakan bahwa tidak ada bantuan dari temannya ketika mereka membutuhkan. Kemudian, 6 siswa (60\%) menyatakan menerima masukan dari teman kelompok saat mengerjakan tugas kelompok bersama-sama. Terdapat juga 5 siswa (50\%) yang menyatakan bahwa mereka pernah mendapat pujian dari teman sekelasnya ketika mendapatkan nilai diatas rata-rata saat hasil ulangan dibagikan. Selain itu dengan adanya budaya KORSA yang digalakkan di lingkungan SMA "X" Bandung, 5 orang siswa (50\%) mengaku mengetahui arti dari budaya KORSA yang mengharuskan saling membantu diantara siswa namun tidak merasakan bentuk nyata dari dukungan yang diberikan oleh teman- 
temannya kehidupan sekolah sehari-hari. Dari survei awal yang dilakukan, diketahui bahwa penghayatan peers support pada siswa kelas X SMA "X” Bandung cukup beragam.

Berdasarkan survei awal yang dilakukan, siswa kelas X SMA "X" yang memiliki penghayatan peers support yang beragam yaitu siswa-siswa yang merasakan bentuk-bentuk dukungan dari teman sebayanya juga memiliki keterlibatan yang beragam di dalam mengikuti kegiatan sekolah. Hal ini sejalan dengan teori yang menyatakan peer support atau dukungan sosial dari teman sebaya berhubungan dengan tingginya school engagement di sekolah (Perdue, Mansezke \& Estell, dalam Estell \& Perdue, 2013). Namun, dari beberapa penelitian yang ditemukan oleh peneliti, masih belum terdapat penelitian pengaruh penghayatan peers support terhadap school engagement yang dilakukan pada jenis sekolah berasrama / boarding school yang di dalamnya memungkinkan terjadinya peers support antara siswa dalam lingkup yang lebih luas, tidak hanya di sekolah namun juga di lingkungan sekolah saat tidak berada di kelas seperti SMA "X” Bandung. Selain itu belum diketahui pula seberapa besar pengaruh peers support terhadap tipetipe school engagement yaitu behavioral, emotional, dan cognitive engagement pada siswa kelas X SMA “X” Bandung.

Dalam penelitian ini menggunakan teori social support yang dikemukakan House (1981 dalam Vaux, 1988) dan teori school engagement yang dikemukakan oleh Fredericks, 2004. House (1981 dalam Vaux, 1988) menyatakan bahwa dukungan merupakan transaksi interpersonal yang melibatkan satu atau lebih dari adanya perhatian dalam bentuk emosional, bantuan instrumental, informatif dan appraisal. Terdapat empat buah bentuk dukungan sosial (House, 1981 dalam Vaux, 1988), yaitu dukungan emosional yang mengacu pada perhatian yang didapatkan dari lingkungan sosial berupa mendengarkan keluh kesah, mengekpresikan keprihatinan, menghibur, memberikan dorongan dalam mengatasi masalah yang sedang dihadapi oleh seseorang. Dukungan instrumental yaitu perhatian yang diberikan secara langsung, yang didapatkan dari lingkungan sosial seperti bantuan uang, barang, jasa maupun 
bantuan lain yang diberikan secara nyata (seperti membantu mengerjakan tugas) untuk mengatasi masalah yang sedang dihadapi seseorang. Dukungan informasi yaitu perhatian yang didapatkan dari lingkungan sosial dalam bentuk seperti memberikan saran, nasihat, panduan, memberikan suatu informasi, memberikan umpan balik terhadap apa yang sudah dilakukan untuk mengatasi masalah yang sedang dihadapinya. Dukungan appraisal yaitu perhatian yang didapatkan dari lingkungan sosial dalam bentuk rasa hormat, menunjukan penghargaan yang positif kepada individu agar individu merasa bahwa dirinya berharga, memiliki kemampuan untuk mengatasi masalah yang sedang dihadapinya.

School engagement dikonseptualisasikan sebagai konstruk multidimensional yang meliputi tipe behavioral, emotional, dan cognitive engagement (Fredericks, Blumenfeld \& Paris, 2004). Pertama, Behavioral engagement menggambarkan ide tentang partisipasi, meliputi keterlibatan siswa dalam aktivitas akademik, sosial, dan ekstrakulikuler. Behavioral engagement didefinisikan dalam tiga cara yaitu positive Conduct, yaitu tingkah laku positif seperti mengikuti aturan dan taat pada norma-norma kelas, termasuk tidak memunculkan tingkah laku mengganggu, meninggalkan sekolah dan mendapat masalah, Involvement in learning and academic tasks, yaitu partisipasi dalam belajar di kelas dan tugas-tugas akademik, dan bertingkah laku seperti tekun, berusaha mengerjakan tugas, perhatian, bertanya dan partisipation in school-related activities, yaitu partisipasi dalam aktivitas sekolah terkait, seperti keikutsertaan dalam kegiatan ekstrakurikuler. Emotional engagement menggambarkan ide tentang appeal/ daya tarik, meliputi reaksi positif dan negatif terhadap guru, teman sebaya, tugas sekolah/akademik, dan sekolah; merupakan reaksi afektif siswa di dalam kelas dan di sekolah. Emotional engagement didefinisikan sebagai reaksi emosi positif terhadap guru, teman, tugastugas dan sekolah secara umum. Cognitive engagement menggambarkan ide tentang investasi/ komitmen yang menggabungkan aktivitas berpikir dan keinginan untuk mengeluarkan usaha yang diperlukan untuk mastery (menguasai materi). Cognitive 
Vol. 2 No.2, Agustus-2020

engagement didefinisikan dalam dua cara yaitu psychological investment in learning, yaitu usaha untuk memahami dan menguasai pengetahuan dan strategic learning, yaitu membuat perencanaan dan menggunakan strategi belajar.

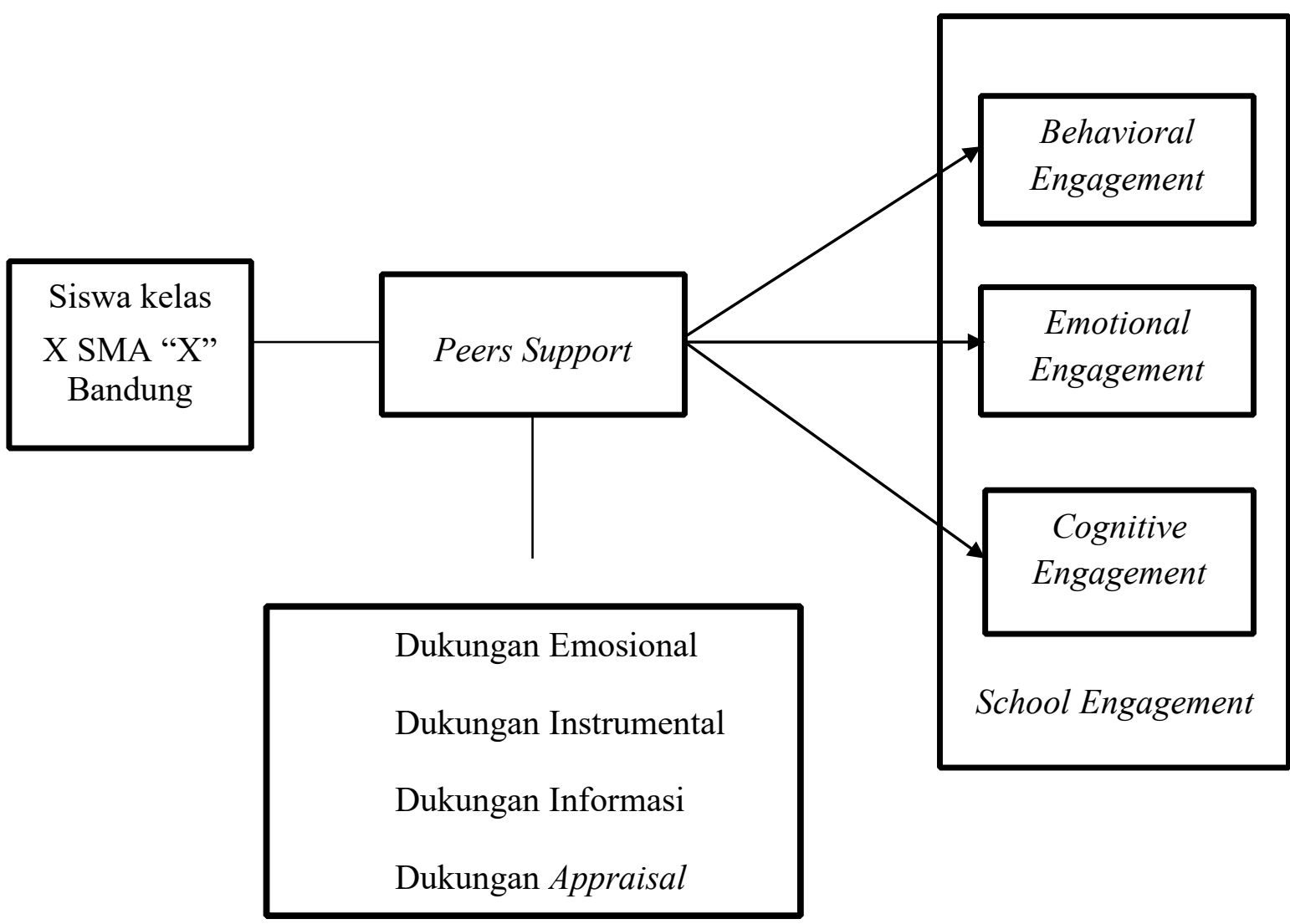

\section{Gambar 1. Kerangka Penelitian}

School engagement siswa kelas X SMA "X" Bandung dapat dilihat dari tiga tipe yang berbeda, yaitu behavioral, emotional dan cognitive. Peers support yang dihayati oleh siswa kelas X SMA "X” Bandung meliputi dukungan emosional, dukungan instrumental, dukungan informasi dan dukungan penghargaan. Peers support memiliki keterkaitan terhadap tipe - tipe school engagement pada siswa kelas X SMA "X” Bandung. 


\section{METODE PENELITIAN}

Penelitian ini menggunakan metode pengaruh dengan tujuan untuk melihat seberapa besar pengaruh dari suatu set variabel (X) terhadap variabel lainnya (Y) (Furlong, 2000). Metode ini dilakukan untuk melihat pengaruh peers support terhadap school engagement pada siswa kelas $\mathrm{X}$

SMA "X" Bandung. Metode pengambilan data yang digunakan adalah dengan menggunakan kuesioner untuk mengumpulkan data. Penelitian ini menggunakan alat ukur berupa kuesioner yang disusun sendiri oleh peneliti berdasarkan teori peers support oleh House (1981) yang berjumlah 39 item yang terdiri dari 24 item positif dan 15 item negatif dan alat ukur school engagement yang disusun oleh Savitri (2018) berdasarkan teori dari Fredericks, et al. (2004), Alat ukur ini terdiri dari 28 item dengan 11 item mewakili tipe behavioral engagement, 9 item mewakili tipe emotional engagement, dan 8 item mewakili tipe cognitive engagement. Kedua alat ukur memiliki 4 pilihan jawaban yaitu sangat sering, sering, jarang, dan sangat jarang. Alat ukur peers support memiliki reliabilitas sebesar 0,894 dan alat ukur school engagement memiliki reliabilitas sebesar 0,818 yang berarti keduanya memiliki reliabilitas yang tinggi. Kemudian hasil perolehan data responden dari kedua kuesioner dihitung pengaruhnya dengan menggunakan teknik analisis regresi linear dengan bantuan program SPSS. Teknik analisis regresi adalah teknik yang digunakan untuk mengetahui pengaruh dari satu variabel pada variabel lain (Gulo, 2002).

\section{HASIL PENELITIAN}

Hasil yang telah diperoleh dalam penelitian ini adalah pengaruh penghayatan peers support terhadap behavioral engagement, emotional engagement, dan cognitive engagement pada siswa kelas X SMA “X” Bandung yang berjumlah 292 siswa. 
Tabel 1. Behavioral engagement

\begin{tabular}{llrrrrl}
\hline Beta $(\beta)$ & Std. Error & $\mathbf{R}$ & $\boldsymbol{R}^{\mathbf{2}}$ & Sig & $\alpha$ & Kesimpulan \\
\hline 0,420 & 0,012 & 0,420 & 0,177 & 0,000 & 0,05 & $\mathrm{H}_{0}$ ditolak \\
\hline
\end{tabular}

Tabel 2. Emotional engagement

\begin{tabular}{llrrrrl}
\hline Beta $(\beta)$ & Std. Error & $\mathbf{R}$ & $\boldsymbol{R}^{2}$ & Sig & $\alpha$ & Kesimpulan \\
\hline 0,486 & 0,012 & 0,486 & 0,236 & 0.000 & 0,05 & $\mathrm{H}_{0}$ ditolak \\
\hline
\end{tabular}

Tabel 3. Cognitive engagement

\begin{tabular}{ccrrrrl}
\hline Beta $(\beta)$ & Std. Error & $\mathbf{R}$ & $\boldsymbol{R}^{\mathbf{2}}$ & Sig & $\alpha$ & Kesimpulan \\
\hline 0,363 & 0,012 & 0,363 & 0,132 & 0.000 & 0,05 & $\mathrm{H}_{0}$ ditolak \\
\hline
\end{tabular}

\section{DISKUSI}

Berdasarkan hasil pengolahan data, diperoleh hasil bahwa penghayatan peers support yang dimiliki siswa kelas X SMA "X" Bandung memiliki pengaruh yang signifikan terhadap behavioral engagement siswa $\left(\mathrm{R}^{2}=0.420, \mathrm{p}<0.001\right)$. Hal tersebut dapat dilihat dari nilai sig $<$ 0,05 (tabel 4.4). Nilai koefisien determinasi $\left(\mathrm{R}^{2}\right)$ sebesar $17,7 \%$ atau dibulatkan sebesar $18 \%$ maka hal tersebut berpengaruh positif, artinya jika semakin sering siswa kelas X SMA "X" Bandung menghayati peers support dalam kehidupannya di SMA"X", maka akan semakin tinggi pula behavioral engagement yang dimiliki siswa tersebut. Hal ini sejalan dengan teori yaitu Penerimaan dari teman sebaya pada masa kanak-kanak dan remaja berhubungan dengan kepuasan di sekolah yang merupakan emotional engagement juga berhubungan dengan perilaku yang sesuai secara sosial dan usaha dalam belajar yang merupakan behavioral engagement (Berndt \& Keefe, 1995; Ladd, 1990; Wentzel, 1994 dalam Fredericks et al., 2004). Teman sebaya dianggap dapat memotivasi siswa untuk terlibat dalam sekolah serta dalam kegiatan ekstrakurikuler yang diadakan. Teman sebaya merupakan bagian yang utama dalam sekolah karena seringkali siswa menghabiskan waktu dengan teman satu kelas dan teman-teman di sekolah. Bahkan ketika siswa memiliki teman sebaya dan merasa secara sosial terhubung, 
merasa didukung, dapat memengaruhi siswa untuk merasa positif terhadap tugas-tugas akademis dan kegiatan sekolah lainnya (Christenson et al, 2012). Budaya KORSA yang menjadi ciri khas di dalam kehidupan siswa kelas X SMA "X" Bandung juga memiliki pengaruh terhadap behavioral engagement yang dimiliki siswa. Siswa kelas $\mathrm{X}$ akan membantu siswa lain yang membutuhkan bantuan dalam pelajaran, memberikan semangat, memberikan informasi terkait kegiatan di sekolah sehingga siswa dengan budaya KORSA ini akan lebih terlibat di dalam kegiatan sekolah baik akademik maupun non-akademik.

Kemudian, berdasarkan perhitungan statistik penghayatan peers support yang dimiliki siswa kelas X SMA “X” Bandung memiliki pengaruh yang signifikan terhadap emotional engagement siswa $\left(\mathrm{R}^{2}=0.486, \mathrm{p}<0.001\right)$. Hal tersebut dapat dilihat dari nilai sig $<0,05$ (tabel 4.5). Nilai koefisien determinasi $\left(\mathrm{R}^{2}\right)$ sebesar $23,6 \%$ atau dibulatkan sebesar $24 \%$ maka hal tersebut berpengaruh positif, artinya jika semakin sering siswa kelas X SMA " $\mathrm{X}$ " Bandung menghayati peers support dalam kehidupannya di SMA"X", maka akan semakin tinggi pula emotional engagement yang dimiliki siswa tersebut.

Hal ini sejalan dengan teori yang menyatakan bahwa terdapat pengaruh teman sebaya terhadap emotional engagement siswa. Penerimaan dari teman sebaya pada masa kanak-kanak dan remaja berhubungan dengan kepuasan di sekolah yang merupakan emotional engagement juga berhubungan dengan perilaku yang sesuai secara sosial dan usaha dalam belajar yang merupakan behavioral engagement (Berndt \& Keefe, 1995; Ladd, 1990; Wentzel, 1994 dalam Fredericks et al., 2004). Sebaliknya dari penelitian diketahui siswa yang ditolak selama masa sekolah dasar lebih beresiko memiliki perilaku buruk dan kurang berpartisipasi di kelas yang merupakan behavioral engagement. Selain itu, memengaruhi kurangnya minat di sekolah yang merupakan emotional engagement (Buhs \& Ladd, 2001; DeRosier, Kupersmidt, \& Patterson, 1994 dalam Fredericks et al., 2004). Budaya KORSA di SMA "X" Bandung membuat siswa saling peduli satu sama lain termasuk ketika secara emosional siswa merasa tidak nyaman 
Vol. 2 No.2, Agustus-2020

dengan guru atau aturan sekolah, merasa tidak tertarik atau sedang kekurangan motivasi dalam mengikuti kegiatan sekolah. Siswa yang sedang mengalami keadaan-keadaan tersebut dapat mengandalkan temannya untuk berbagi beban pikiran, menceritakan masalahnya sehingga beban yang ditanggung dapat diatasi bersama-sama.

Hal ini akan memperkuat emotional engagement yang dimiliki siswa kelas X SMA "X" Bandung. Terakhir, berdasarkan perhitungan statistik penghayatan peers support yang dimiliki siswa kelas X SMA "X" Bandung memiliki pengaruh yang signifikan terhadap cognitive engagement siswa $\left(\mathrm{R}^{2}=0.363, \mathrm{p}<0.001\right)$. Hal tersebut dapat dilihat dari nilai sig $<$ 0,05 (tabel 4.6). Nilai koefisien determinasi $\left(\mathrm{R}^{2}\right)$ sebesar $13,2 \%$ atau dibulatkan sebesar $13 \%$ maka hal tersebut berpengaruh positif, artinya jika semakin sering siswa kelas X SMA " $\mathrm{X}$ " Bandung menghayati peers support dalam kehidupannya di SMA"X", maka akan semakin tinggi pula cognitive engagement yang dimiliki siswa tersebut.

Hal ini sejalan dengan teori bahwa dukungan akademik memiliki pengaruh yang lebih besar dalam meningkatkan motivasi untuk berprestasi dan berpartisipasi dalam kelas dibandingkan dukungan emosional (Wentzel et al., 1994). Dukungan akademik merupakan tindakan membantu orang lain di kelas, mempersiapkan strategi-strategi yang edukasional dan saran bagi siswa dalam mengerjakan aktivitas di sekolah (Thompson \& Mazer, 2009). Budaya KORSA yang diterapkan dalam keseharian siswa kelas X SMA " $X$ ” Bandung juga terlihat di dalam proses belajar. Bila ada siswa yang kesulitan memahami materi pelajaran, maka siswa lain akan membantu dengan mengajarkan cara belajar yang lebih mudah, strategi-strategi yang dapat digunakan untuk menyelesaikan suatu persoalan yang sulit. Hal tersebut dapat memperkuat usaha siswa kelas X SMA "X" Bandung dalam mengerahkan kognisi dan menggunakan strategi dalam belajar.

Pengaruh lain terhadap school engagement siswa kelas X SMA "X” Bandung juga bisa disebabkan oleh faktor lain yang tidak diteliti oleh peneliti. Faktor-faktor tersebut antara lain 
school level factors, teacher support, classroom structure, autonomy support, task characteristics dan individual needs. Faktor-faktor tersebut yang bisa memengaruhi school engagement siswa misalnya teacher support, SMA "X" Bandung yang merupakan sekolah boarding school memungkinkan terjadinya interaksi yang frekuensinya lebih sering atau intens antara siswa dan guru baik selama kegiatan di sekolah maupun di luar sekolah sehingga faktor ini bisa memengaruhi keterlibatan siswa.

Dari hasil penelitian pengaruh peers support secara keseluruhan signifikan terhadap tipe - tipe school engagement yang dimiliki oleh siswa kelas X SMA "X" Bandung. Tiap-tiap bentuk peers support yaitu dukungan emosional, dukungan instrumental, dukungan informasi, dan dukungan appraisal dapat ditingkatkan agar school engagement yang dimiliki siswa bisa lebih baik. Selain itu budaya KORSA yang sudah mengakar di dalam diri siswa SMA " $X$ " Bandung harus tetap dijaga karena memiliki pengaruh terhadap keterlibatan siswa (school engagement) dalam mengikuti kegiatan di sekolah Maka dari itu, berdasarkan penelitian, untuk meningkatkan school engagement siswa kelas X SMA "X" Bandung pihak sekolah dapat berupaya untuk meningkatkan peers support antara siswa kelas X SMA “X” Bandung.

\section{KESIMPULAN DAN SARAN}

Berdasarkan hasil penelitian serta pembahasan pengaruh peers support terhadap school engagement siswa kelas X SMA "X” Bandung, dapat disimpulkan bahwa:

1. Peers support dapat meningkatkan behavioral engagement pada siswa kelas X SMA " $\mathrm{X}$ " Bandung.

2. Terdapat pengaruh dari peers support terhadap emotional engagement pada siswa kelas $\mathrm{X}$ SMA "X" Bandung. Dalam penelitian ini emotional engagement merupakan tipe school engagement yang paling besar dipengaruhi oleh peers support. 
3. Peers support dapat meningkatkan cognitive engagement pada siswa kelas X SMA " $\mathrm{X}$ " Bandung.

Berdasarkan hasil penelitian tersebut, maka diharapkan pihak sekolah khususnya wali asuh atau guru BK dapat memberikan program psikoedukasi terhadap siswa kelas X SMA "X" Bandung mengenai pentingnya dan pengaruh dari peers support (dukungan teman sebaya) terhadap school engagement siswa kelas X SMA “X” Bandung. Selain itu, pihak sekolah dapat memertahankan budaya KORSA yang telah terjalin pada siswa SMA "X” Bandung karena hal tersebut merupakan budaya yang mendukung terjalinnya peers support yang lebih kuat antara sesama siswa kelas X SMA "X” Bandung. Sekolah dapat membuat kegiatan atau program yang memfokuskan pada bagaimana siswa kelas X SMA "X" Bandung dapat memberikan reaksi emosi yang lebih positif pada teman sebaya, guru, sekolah, maupun akademik.

\section{DAFTAR PUSTAKA}

Christenson, Sandra L., Wylie, Cathy., Reschly, Amy L. (2012). Handbook of Research on Student Engagement. USA: Springer.

Fredericks, Jennifer A., Blumenfeld, Phyllis C., Paris, Alison H. (2004). Review of Educational

Research. School engagement: Potential of the Concept, State of the Evidence. American Educational Research and Sage.

Guilford, J. P. (1973). Fundamental Statistics in Psychology and Education. New York: Mc Graw-Hill Book Co. Inc.

Himpsi. (2010). Kode Etik Psikologi Indonesia. Jakarta: Pengurus Pusat Himpunan Psikologi Indonesia.

Santrock, J. W. (2003). Adolenscene: Perkembangan Remaja. Alih Bahasa: Adelar, S.B. \& Saragih, S. Jakarta: Erlangga.

Santrock, J. W. (2007). Psikologi Perkembangan. Edisi 11 Jilid 1. Jakarta: Penerbit Erlangga. Santrock, J. W. (2011). Educational Psychology (5th Edition ed.). New York: Mc Graw Hill. Savitri, J. (2018). Pengaruh Parent Involvement, Parent Autonomy Support dan Parental Structure terhadap School engagement melalui Basic Needs Satisfaction pada Siswa Kelas 4-6 Sekolah Dasar di Bandung. Disertasi.

Sugiyono. (2003). Statistika untuk penelitian. Bandung: CV Alfabeta.

Vaux, Alan. (1988). Social Support: Theory, Research, and Intervention. New York: Praeger. Wijanto, S. H. (2008). Structural Equation Modelling, dengan Lisrel 8.8 Konsep \& Tutorial. Yogyakarta: Graha Ilmu. 